Document downloaded from:

http://hdl.handle.net/10251/160821

This paper must be cited as:

Llario, F.; Rodilla, M.; Falco, S.; Escrivá, J.; Sebastiá-Frasquet, M. (2020). Periphyton and phytoplankton assessment in a shrimp nursery: signature pigments analysis. International Journal of Environmental Science and Technology. 17(2):857-868.

https://doi.org/10.1007/s13762-019-02515-z

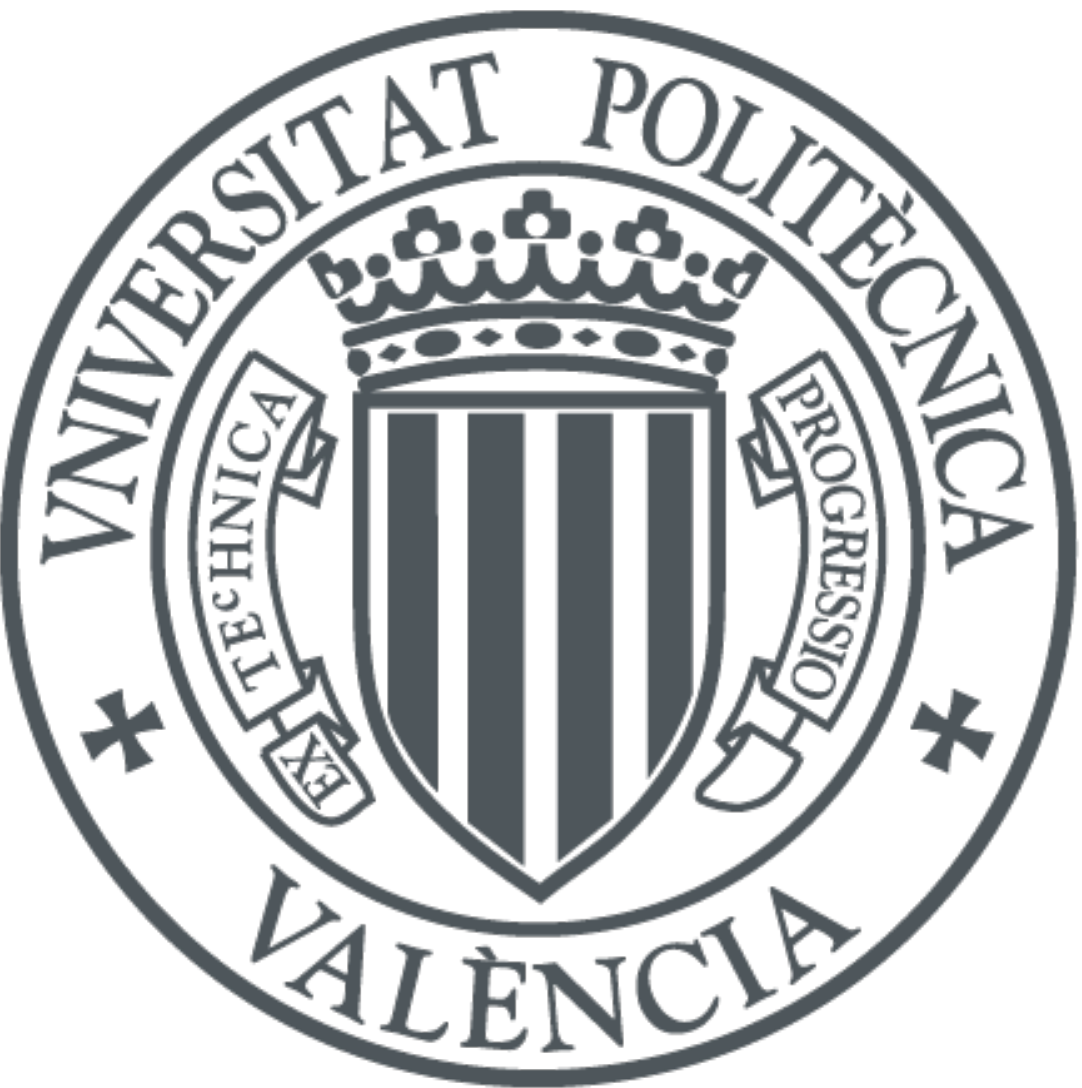

The final publication is available at

https://doi.org/10.1007/s13762-019-02515-z

Copyright Springer-Verlag

Additional Information 


\title{
Periphyton and phytoplankton assessment in a shrimp nursery: signature pigments analysis
}

\author{
Ferran Llario ${ }^{1}$, Miguel Rodilla ${ }^{2}$, Silvia Falco ${ }^{3}$, Julia Escrivá, Maria Teresa Sebastiá-Frasquet ${ }^{4}$ \\ Affiliation: Institut d'Investigació per a la Investigació de Zones Costaneres (IGIC), Universitat Politècnica de \\ València. Paranimf, 1. 46730 Grau de Gandia (València, Spain). Phone number: (+34)962849333 \\ ${ }^{1,4}$ corresponding authors: ${ }^{1}$ ferllase@ upv.es $;{ }^{4}$ mtsebastia@hma.upv.es
}

\begin{abstract}
Microalgae play a fundamental role in aquaculture systems, especially in nurseries. They can supplement the nutrition of cultured species, and also contribute to keep good water quality. Their value depends on the groups present in major abundance. Thus, being able to understand the factors that influence microalgae composition is key for an improved system management. In this study, the microalgae community structure in a Marsupenaeus japonicus nursery is studied. Instead of the classic microscopy approach, the composition and abundance of periphyton and phytoplankton were analyzed using signature pigments analysis by high pressure liquid chromatography coupled with the software CHEMTAX. The environmental parameters, which could affect periphyton and phytoplankton groups, were analyzed statistically. The results showed that diatoms were the dominant group both in phytoplankton and periphyton. The analysis of signature pigments, allowed to report the presence of previously undetected groups on periphyton, prasinophytes and prymnesiophytes, which are characterized by a high nutritional value. This is especially important in nurseries because of shrimp grazing on periphyton can increase post-larvae survival. Nutrients played a key role on phytoplankton development, but had a minor effect on periphyton, which was more affected by colonization processes and other environmental variables.
\end{abstract}

Keyword: biofilm; CHEMTAX; Marsupenaeus japonicus; microalgae; high-performance liquid chromatography 


\section{INTRODUCTION}

Microalgae play a crucial role in aquaculture tanks, both as a feed and for its ability to maintain good water quality (Ballester et al. 2007; Khatoon et al. 2007a; Anand et al. 2013). These microalgae can be phytoplankton, the autotrophic component of plankton that drifts in the water column (Harris 2012); or periphyton, which grows fixed on the substrate (Azim et al. 2005). By origin, they can come from specific cultures or develop naturally in the environment. Cultured microalgae usually come from intensive monocultures and are provided to the cultured species (e.g. shrimps) in different ways: lyophilized and included in the feed (Macias-Sancho et al. 2014), as live feed (Barbieri and Ostrensky 2001; Brito et al. 2016) or fixing them on a substrate that is later supplied to the cultured species (Khatoon et al. 2007b). The effects of microalgae vary according to their abundance and taxonomic composition. Previous studies have shown that there are groups of microalgae, such as diatoms, able to improve water quality, and with high nutritional value (Khatoon et al. 2007b). In contrast, other groups, such as cyanobacteria, are highly toxic, and have a negative effect on survival and growth of cultured species (Alonso-Rodríguez and Páez-Osuna 2003; Sinden and Sinang 2016).

The dynamics of microalgae in aquaculture systems respond to a complex relationship between different environmental and biological variables (Alonso-Rodríguez and Páez-Osuna 2003; Pandey et al. 2014; Llario et al. 2018). Being able to understand these dynamics can help shrimp farmers to manipulate aquaculture systems for keeping the most desired microalgae composition. However, most studies have focused on phytoplankton dynamics, while periphyton studies are scarcer. Temperature, light and nutrients are environmental variables that have a key effect on microalgae abundance and composition (Yusoff et al. 2002; Zhang et al.2009). In general, low N:P ratios facilitate undesired species such as dinoflagellates and cyanobacteria blooms in aquaculture tanks (Alonso-Rodríguez and Páez-Osuna 2003), while high silica levels favors diatoms (Llario et al. 2018). For periphyton, is also of paramount importance the effect of substrate. Substrates such as bamboo, plastic sheet, polyvinylchloride, polyethylene, fibrous scrubber, ceramic, paddy straw and coconut fronts have been tested by some authors (Thompson et al. 2002; Khatoon et al. 2007a; Anand et al. 2013; Schveitzer et al. 2013; Sruthisree et al. 2015). Also, shrimp graze on periphyton (Ballester et al. 2007) and the substrates colonizing potential of some microalgae species can be relevant factors (Khatton et al. 2007a; Zhang et al. 2012).

Periphyton studies are scarce mainly due to sampling and analysis complexity. In general, the recollection of periphyton, from different aquaculture systems, is based on the suspension of the periphyton in water and its subsequent analysis following the techniques described for phytoplankton (Kahoon et al. 2007a; Anand et al. 
2013). Some studies scrape the periphyton from the substrate and add preservatives such as formaldehyde for its preservation (Azim et al. 2001). Others, fix the periphyton on the substrate with lugol or formaldehyde and then resuspend the periphyton with the help of an ultrasonic homogenizer or a vortex (Anand et al. 2013; Viau et al. 2013). Taxonomic groups are usually identified by optic microscopy (Azim et al. 2001; Thompson et al. 2002; Kahoon et al. 2007a; Anand et al. 2013; Viau et al. 2013). However, this technique involves hard work, and its results generally underestimate the groups with smaller size or those with lower abundance (Gocke et al. 2003; Devilla et al. 2005; Silva et al. 2008). In the last decades, the analysis of signature pigments by highperformance liquid chromatography (HPLC) has arisen as a reliable technique to supplement microscope counts (Schlüter et al. 2006). This technique has already been successfully used for the analysis of phytoplankton from aquaculture tanks, both for analysis of point samples (Jiang et al. 2016; Lemonnier et al. 2016) and for complete monitoring of a culture (Llario et al. 2018). In this study, we aim to prove that it is also useful for periphyton analysis.

The primary objective of this research was to estimate microalgae community structure in a Marsupenaeus japonicus nursery. Periphyton and phytoplankton composition and abundance were determined using HPLC signature pigment analysis coupled with CHEMTAX software. The secondary objectives were to analyze the environmental parameters that can affect the abundance, composition and development of microalgae in a shrimp nursery.

\section{MATERIAL AND METHODS}

\section{Location and shrimp culture system}

The experiment was developed in the Universitat Politècnica de València facilities (Gandia, Valencia, Spain), between June 2 and July 17, 2015. Postlarvae shrimps (PLs) of M. japonicus were purchased from La Petite Canau (Leucate, Aude, France). The PLs had an initial fresh size of $0.020 \pm 0.008 \mathrm{~g}$. The nursery facilities comprised 9 concrete tanks located inside a greenhouse, and constantly individually aerated. The greenhouse had natural lighting (15 hours every day) and the light intensity was between 3000 and 6000 lux. Water temperature in the tanks was kept at an adequate range thanks to the greenhouse, no heating systems were used. The tanks were covered with polyvinyl chloride (PVC) canvas for waterproofing. Each tank had a surface of $3.2 \mathrm{~m}^{2}$, and was filled with $2250 \mathrm{~L}$ of seawater (36.5 salinity), no water renewal was made during the experiment. The water 
was disinfected with $10 \mathrm{mg} / \mathrm{L}$ of chlorine, which was subsequently removed by adding ascorbic acid to the tanks (Krummenauer et al. 2014). The shrimp were distributed in three densities per triplicate 25 (tanks 5,7 and 8 ), 50 (tanks 1, 3 and 9) and 75 (tanks 2, 4 and 6) shrimp/ $\mathrm{m}^{2}$. Densities were chosen according to usual ones in intensive cultures of M. japonicus (Coman et al. 2004). The feed rate was not the same for the three assayed densities, it was applied following the recommendations by Barbieri and Ostrensky (2001) according to density and shrimp size. Feeding was provided twice a day, with commercial feed specifically designed, composed by $38.00 \%$ of protein and $1.38 \%$ content of phosphate.

\section{Water quality}

During the experiment, dissolved oxygen (DO), salinity and temperature (T) were monitored in-situ, using a multi-parameter probe (YSI ProODO and WTW Multi 340i respectively) twice a day. Freshwater was added to maintain salinity around 36.5 , when the salinity value exceeded 37 . The $\mathrm{pH}$ was measured once a day using $\mathrm{pH}-$ Meter BASIC $20^{+}$Crison.

An initial fertilization of the system was done with sucrose, with a theoretical 15:1 carbon/nitrogen ratio, with the aim of guaranteeing the initial development of heterotrophic bacteria. During the rest of the experiment a $\mathrm{C}: \mathrm{N}$ ratio of 15:1 was maintained, through the addition of a carbon source (sucrose) when TAN values higher than $1 \mathrm{mg} / \mathrm{L}$ were detected (Ebeling et al. 2006).

Every 2 days an aliquot of water was collected to determine the concentration of total dissolved ammonia (TAN $\mathrm{mg} / \mathrm{L})$, nitrites $\left(\mathrm{N}-\mathrm{NO}_{2}{ }^{-} \mathrm{mg} / \mathrm{L}\right)$ and phosphates $\left(\mathrm{P}_{-} \mathrm{PO}_{4}{ }^{3-} \mathrm{mg} / \mathrm{L}\right)$ using the methodology described by Baumgarten et al. (2010). The nitrates $\left(\mathrm{N}-\mathrm{NO}_{3}{ }^{-} \mathrm{mg} / \mathrm{L}\right)$ were analyzed twice a week, by means of the difference between nitrites plus nitrates using the methodology described by Grasshoff (1976).

\section{Biological parameters}

Before the experiment, pieces of $200 \mathrm{~cm}^{2}$ of PVC canvas were submerged at a depth of $30 \mathrm{~cm}$ from the surface. Pieces of canvas of about $20 \mathrm{~cm}^{2}$ were cut for the analysis of periphyton once a week (Hagerthey et al. 2006). Water samples for phytoplankton pigment analysis were filtered on GF/F fiberglass filters (25 mm diameter and $0.7 \mu \mathrm{m}$ pore) once a week. Photosynthetic pigments were extracted using acetone (100\% HPLC grade) and were measured using reverse-phase high-performance liquid chromatography (HPLC). The HPLC method employed was that proposed by Wright et al. (1991) slightly modified as per Hooker et al. (2001). The system was 
calibrated with external standards obtained commercially from the DHI Water and Environment Institute (Hørsholm, Denmark). For more details on the benefits of this analytical procedure see Sebastiá et al. (2012).

Once the concentration of important photosynthetic pigments was determined, the phytoplankton community was studied using the CHEMTAX software (Mackey et al. 1996) version 1.95 (S. Wright, pers. comm.) to obtain the contribution to total chlorophyll $a(\mathrm{Chl} a)$ from the phytoplankton and periphyton groups identified with microscopy as described in Sebastiá et al. (2012) and Sebastiá and Rodilla (2013). In order to identify groups of samples with similar characteristics, a cluster analysis was performed using STATGRAPHICS Centurion XVI.I to group samples according to pigments concentration. CHEMTAX was applied independently to obtain the contribution of eight phytoplankton and periphyton groups to the Chla stock: diatoms, dinoflagellates, euglenophytes, chlorophytes, cryptophytes, prymnesiophytes, prasinophytes, and cyanobacteria. The final matrix used to estimate the contribution of the different groups to Chla stock is published in Llario et al. (2018).

The HPLC/CHEMTAX is an appropriate tool for identifying and quantifying algal groups, but it does not allow to identify genus or species. The inverted microscope was used punctually, for routine check of groups as recommended by standards of use of signature pigments (Roy et al. 2011). Phytoplankton samples were fixed with formaldehyde, concentrated according to UNE EN15204:2006, based on Utermohl (1958), and qualitatively examined under a LEICA DM IL inverted microscope. Periphyton samples were scraped and suspended in filtered seawater (Azim et al. 2001), for subsequent treatment in the same way as phytoplankton.

\section{Statistical analysis}

Previously to statistical analysis, we calculated weekly average of environmental parameters to be able to compare with phytoplankton and periphyton data, which were sampled weekly. Normality and homocedasticity of all variables were tested before multivariate analysis. As all the variables were not normally distributed, a non-parametric one-way analysis of variance (Kruskal-Wallis) was performed to statistically assess variations in the median fraction of all monitored variables within the experimental tanks. Spearman rank correlation analyses were performed on environmental and biological variables (salinity, $\mathrm{pH}, \mathrm{T}, \mathrm{DO}, \mathrm{TAN}, \mathrm{N}-\mathrm{NO}_{2}^{-}, \mathrm{N}-\mathrm{NO}_{3}{ }^{-}, \mathrm{P}_{-}-\mathrm{PO}_{4}{ }^{3-}$, total Chla in phytoplankton and total Chla in periphyton) with phytoplankton or periphyton groups in order to examine significant relationship. The significant relationship between phytoplankton and periphyton groups was also assessed. 


\section{RESULTS AND DISCUSSION}

During the experiment, no statistically significant differences were observed on physicochemical variables within the experimental tanks according to Kruskal-Wallis analysis results $(P>0.05)$. Salinity, $\mathrm{pH}$ and dissolved oxygen were kept stable under conditions suitable for the culture of M. japonicus (Blachier 1998; Barbieri and Ostrensky 2001). The average recorded salinity was 36.5 ; this value increased to 37.2 due to water evaporation, but freshwater was added to avoid exceeding this limit (minimum salinities of 35.6 were due to freshwater supply). The $\mathrm{pH}$ was stable during all the experiment with values between 8.41 and 8.68 . Dissolved oxygen increased slightly from 5.86 to $6.75 \mathrm{mg} / \mathrm{L}$ by the end of the experiment. The temperature was generally maintained at optimum levels for the culture of $M$. japonicus $\left(24\right.$ to $\left.30^{\circ} \mathrm{C}\right)$ according to Preston et al. (1995) and Hewitt and Duncan (2001), with an average of $30.2^{\circ} \mathrm{C}$. Occasionally, water temperature reached $32.1{ }^{\circ} \mathrm{C}$, which is the maximum temperature recommended.

Water quality was kept at adequate values for the development of shrimp. The addition of carbon to maintain the C:N relationship allowed the development of heterotrophic bacteria in the water column. These bacteria participated in the oxidation process of N-TA and ${\mathrm{N}-\mathrm{NO}_{2}}^{-}$controlling their levels (Crab et al. 2012). This process allowed to maintain the water quality without water renewal during the culture. The levels of ammonia and nitrites were maintained within the limits of safety determined by Lin and Chen (2001), to avoid toxic effects on shrimp. TAN average was $0.53 \mathrm{mg} / \mathrm{L}$, but occasionally reached $3.70 \mathrm{mg} / \mathrm{L}$; while $\mathrm{N}^{-} \mathrm{NO}_{2}^{-}$varied between non

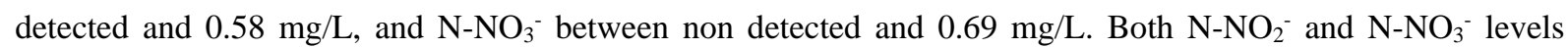
increased along the study period. $\mathrm{P}_{-} \mathrm{PO}_{4}{ }^{3-}$ also increased, with maximum values close to $1 \mathrm{mg} / \mathrm{L}$ during the last culture week. The final fresh weight of shrimps was $0.892 \pm 0.189 \mathrm{~g}$ after 45 days and it did not differ between tanks or densities of shrimps according to Kruskal-Wallis analysis results $(P>0.05)$.

The following signature pigments were detected in water samples (Table 1): peridinin, fucoxanthin, neoxanthin, prasinoxanthin, violaxanthin, diadinoxanthin, alloxanthin, lutein and zeaxanthin. According to pigment analysis, these seven phytoplankton groups were present: diatoms, dinoflagellates, cryptophytes, euglenophytes, prasinophytes, prymnesiophytes and cyanobacteria. A Kruskal-Wallis analysis was performed to detect statistically significant differences in phytoplankton groups abundance between tanks. In Table 2, we summarize phytoplankton statistics both for absolute composition (absolute contribution to chlorophyll $a, \mu \mathrm{g} / \mathrm{L}$ ) and relative composition (percentage of total chlorophyll $a, \%$ ). In tables 1 and 2 , statistically significant differences are 
assessed according to Kruskal-Wallis results. There were no significant differences $(P>0.05)$ in signature pigments and phytoplankton abundances between different densities of shrimp.

Table 1. Concentration of signature pigments and chlorophyll $a$ presents in the phytoplankton . The table show the percentile 10 (P 10), percentile 25 (P 25), percentile 75 (P 75), percentile 90 (P 90), maximum and average \pm standard deviation $(\mathrm{SD})$ values.

\begin{tabular}{|c|c|c|c|c|c|c|}
\hline & \multicolumn{5}{|c|}{ Phytoplankton signature pigments concentration $(\boldsymbol{\mu g} / \mathrm{L})$} \\
\hline Signature pigments & P 10 & P 25 & P 75 & P 90 & Maximum & Average \pm SD \\
\hline Peridinin & 0.00 & 0.00 & 0.00 & 0.00 & 2.94 & $0.06 \pm 0.41$ \\
\hline Fucoxanthin & 0.11 & 0.47 & 4.89 & 11.85 & 26.36 & $3.86 \pm 6.25$ \\
\hline Prasinoxanthin & 0.00 & 0.00 & 0.00 & 0.00 & 1.86 & $0.06 \pm 0.27$ \\
\hline Diadinoxanthin & 0.00 & 0.03 & 0.33 & 1.41 & 7.12 & $0.49 \pm 1.15$ \\
\hline Alloxanthin & 0.00 & 0.00 & 0.00 & 0.00 & 0.24 & $4.70 \times 10^{-3} \pm 3.36 \times 10^{-2}$ \\
\hline Zeaxanthin & 0.00 & 0.00 & 0.00 & 0.23 & 1.60 & $0.06 \pm 0.24$ \\
\hline Chlorophyll $a$ & 0.17 & 0.59 & 5.73 & 20.89 & 58.01 & $7.19 \pm 12.13$ \\
\hline
\end{tabular}

Data obtained from 54 phytoplankton samples $(n=54)$. 
Table 2. Phytoplankton statistics both for absolute and relative contribution to total chlorophyll $a$. The table show the percentile 10 (P 10), percentile 25 ( $\mathrm{P}$ 25), percentile 75 (P 75), percentile 90 (P 90), maximum and average \pm standard deviation $(\mathrm{SD})$ values.

\begin{tabular}{|c|c|c|c|c|c|c|c|c|c|c|}
\hline & \multicolumn{6}{|c|}{ Phytoplankton absolute contribution to chlorophyll $a(\mu \mathrm{g} / \mathrm{L})$} & \multicolumn{4}{|c|}{ Phytoplankton relative cont } \\
\hline Groups & P 10 & $\mathbf{P} 25$ & P 75 & P 90 & Maximum & Average \pm SD & P 10 & P 25 & P 75 & $\mathbf{P} 90$ \\
\hline Diatoms & 0.10 & 0.59 & 5.46 & 20.89 & 57.85 & $6.57 \pm 11.97$ & 77.86 & 99.73 & 100 & 100 \\
\hline Dinoflagellates & 0.00 & 0.00 & 0.00 & $1.14 \times 10^{-3}$ & 4.25 & $0.08 \pm 0.60$ & 0.00 & 0.00 & 0.00 & 0.01 \\
\hline Euglenophytes & 0.00 & 0.00 & 0.00 & 0.02 & 0.10 & $0.01 \pm 0.02$ & 0.00 & 0.00 & 0.00 & 0.17 \\
\hline Cryptophytes & 0.00 & 0.00 & 0.00 & 0.01 & 1.26 & $0.02 \pm 0.18$ & 0.00 & 0.00 & 0.00 & 0.12 \\
\hline Prasinophytes & 0.00 & 0.00 & 0.00 & 0.00 & 4.72 & $0.12 \pm 0.68$ & 0.00 & 0.00 & 0.00 & 0.00 \\
\hline Prymnesiophytes & 0.00 & 0.00 & 0.00 & $1.75 \times 10^{-3}$ & 0.02 & $8.62 \times 10^{-4} \pm 3.09 \times 10^{-3}$ & 0.00 & 0.00 & 0.00 & 0.03 \\
\hline Cyanobacteria & 0.00 & 0.00 & 0.00 & 0.23 & 0.79 & $0.07 \pm 0.21$ & 0.00 & 0.00 & 0.00 & 6.55 \\
\hline
\end{tabular}

Data obtained from 54 phytoplankton samples $(n=54)$

The average phytoplankton biomass was $6.87 \mu \mathrm{g} / \mathrm{L}$ of Chla, but it varied between non detected and $58.01 \mu \mathrm{g} / \mathrm{L}$ during study period. Diatoms were the dominant group of phytoplankton, on average they accounted a $93 \%$ of total Chla, and at specific moments they reached $100 \%$ (Table 2). In Fig. 1, we represented the temporal development of phytoplankton abundance by groups. In this figure, the clear predominance of diatoms along the entire experiment is observed. The mean abundance of other phytoplankton groups was on average lower than $3 \%$. However, both cryptophytes and cyanobacteria arrived to maximum percentages above 50\% (Table 2). Moreover, prasinophytes even get to $100 \%$ of total Chla (Table 2). The incidence of these high percentages was limited since they were isolated cases, that happened on one tank only and disappeared in the next analysis. Prasinophytes bloom was only observed in tank 7 on day 31 , cyanobacteria bloom was detected in tank 1 on day 38 , and cryptophytes bloom happened in tank 5 on day 45. Prasinophytes increased from $0 \%$ to $100 \%$ of Chla in one week in tank 7 and were not detected the next week. That means that sampling frequency, once a week, was not enough to detect an intermediate abundance stage. A higher sampling frequency will be needed to have more information about these blooms development. The phytoplankton in the thanks showed a dynamic similar to natural systems, where it has rapid shifts in composition and abundance (Suda et al. 2002; O'Kelly et al. 2003).

Chla concentration in water is used as a proxy for phytoplankton biomass (Gaona et al. 2011). In this experiment, phytoplankton was first detected on day 10, pigments concentration was below detection level on 
day 3. Before, no Chla was detected due to the initial disinfection of culture water. Water samples from day 10 to day 24 had Chl $a$ concentrations around $3 \mu \mathrm{g} / \mathrm{L}$. During this first phase, only diatoms were observed. Since day 31, an increase in Chla was observed, with concentrations around $12 \mu \mathrm{g} / \mathrm{L}$ by the end of the study period. During this second phase, diatoms were dominant but other phytoplankton groups appeared, such as dinoflagellates $(0.4$ $\mu \mathrm{g} / \mathrm{L}$ on average $)$ and prasinophytes $(0.5 \mu \mathrm{g} / \mathrm{L}$ on average $)$. A maximum $\mathrm{Chl} a$ value of $57.85 \mu \mathrm{g} / \mathrm{L}$ was detected in tank 9 on day 38; however, no statistical differences were detected among tanks when considering the entire period Chla abundance. Chla concentration in aquaculture waters is highly variable, because it depends on a large number of factors (Burford 1997). The Chla values quantified in this experiment in phytoplankton are similar to those observed by other authors (Guerrero-Galvá et al. 1999; Yusoff et al. 2002 and Lemonnier et al. 2016).

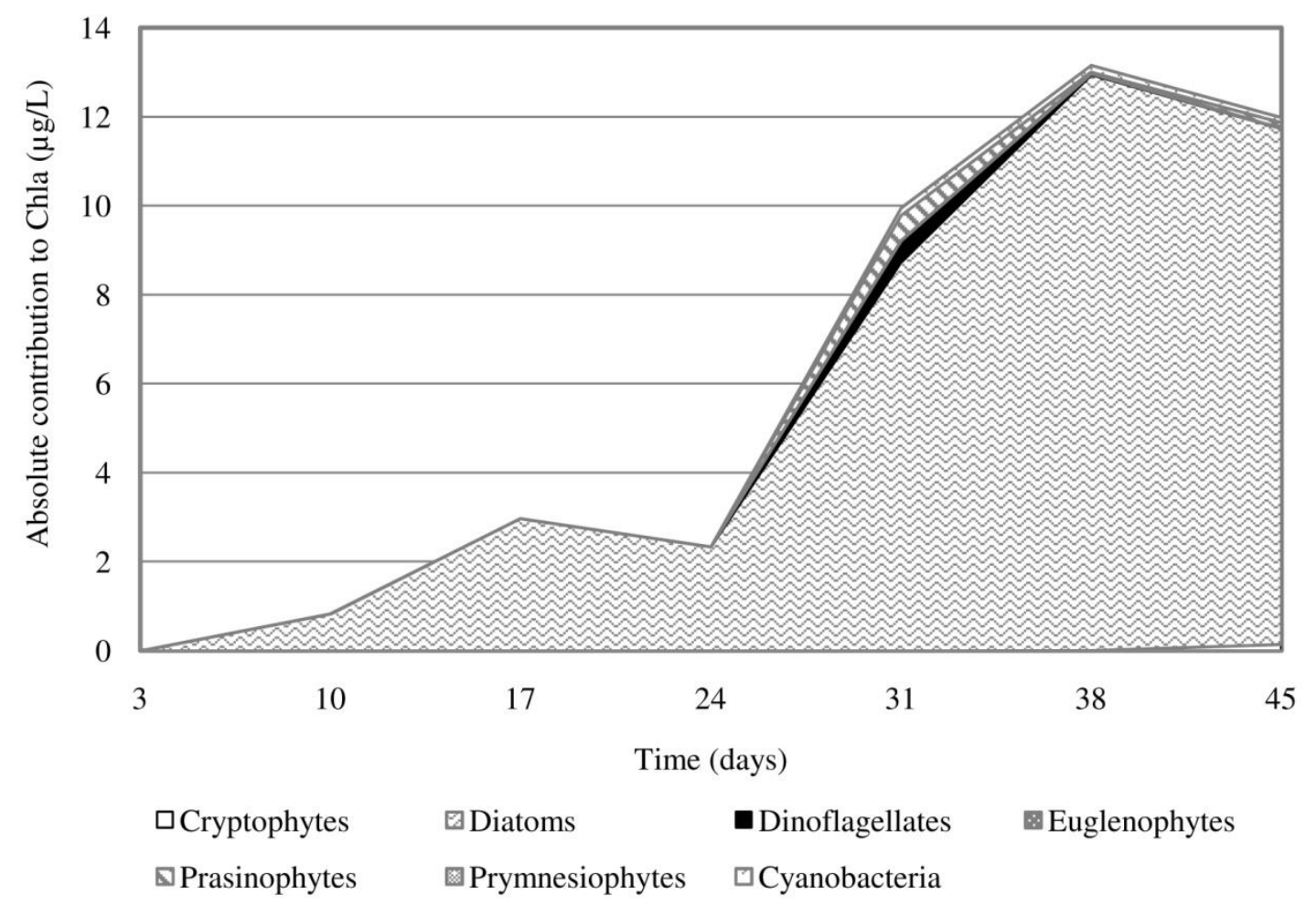

Fig. 1 Phytoplankton groups mean contribution to chlorophyll a concentration $(\mu \mathrm{g} / \mathrm{L})$ temporal evolution. 
In general, diatoms are the dominant group in most shrimp cultures developed in saltwater tanks (Yusoff et al. 2002; Casé et al. 2008; Lemonnier et al. 2016). Environmental variables directly influence phytoplankton and can help us understand phytoplankton dynamics and the dominance of one or another group (Sanders et al. 1987). In this study, salinity and $\mathrm{pH}$ had great stability throughout the culture period, for that reason, these variables do not have a significant correlation with any taxonomic group (Table 3). In contrast, temperature showed a positive correlation with different groups, and dissolved oxygen a negative correlation (Table 3); these correlations were previously observed by Casé et al. (2008) and Llario et al. (2018) in shrimp aquaculture. The maximum growth of diatoms is usually observed between 25 and $30^{\circ} \mathrm{C}$ (Renaud et al. 2002), which is the temperature range used in $M$. japonicus cultures. The proliferation of phytoplankton in aquaculture tanks is accompanied by the increase of bacteria, which decompose the organic matter present in the system and consume oxygen (Paerl and Tucker 1995).

The highest correlations were observed between phytoplankton groups and nutrients $\left(\mathrm{TAN}, \mathrm{N}-\mathrm{NO}_{2}{ }^{-}, \mathrm{N}^{-} \mathrm{NO}_{3}{ }^{-}\right.$and $\left.\mathrm{P}-\mathrm{PO}_{4}{ }^{3-}\right)$. Minor phytoplankton groups correlated significantly with a single nutrient each, while diatoms showed a significant positive correlation with the four nutrients analyzed (Table 3). Diatoms dominance in phytoplankton (93\% relative contribution to $\mathrm{Chl} a$ ) is explained by their rapid use of nutrients and their high growth rate (Ryther and Officer 1981). While other groups of phytoplankton have a preference for some forms of nitrogen (Paerl and Tucker 1995; Šupraha et al. 2014; Reed et al. 2016), diatoms rapidly consumes nitrogen in all its forms (Ryther and Officer 1981). The decrease or depletion of silica usually causes the decline of diatoms and proliferations of cyanobacteria (Casé et al. 2008). In this experiment, the tanks were filled with coastal waters from Gandia Harbor characterized by high silica levels (Sebastiá et al. 2012; Sebastiá and Rodilla 2013). This high initial silica content can maintain important diatom abundances in aquaculture tanks longer periods than usual (Llario et al. 2018), which explains why their decrease was not observed. The presence of diatoms in shrimp nurseries is highly desired due to its high nutritional value (Kent et al. 2011), and its efficiency in the removal of nutrients helps to maintain water quality (Khatoon et al. 2007b). 
Table 3. Rank correlation matrix (Spearman's) between environmental and biological variables (Salinity, T -

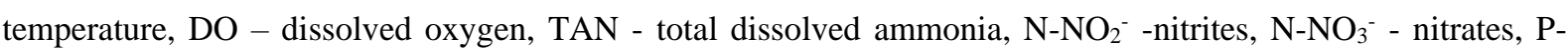
$\mathrm{PO}_{4}{ }^{3-}$ - phosphates, and Pe-Chl $a$ - total chlorophyll $a$ in the periphyton) and phytoplankton groups.

\begin{tabular}{|c|c|c|c|c|c|c|c|c|c|}
\hline & Salinity & $\mathrm{pH}$ & $\overline{\mathrm{DO}}$ & $\mathrm{T}$ & TAN & $\mathrm{N}^{-\mathrm{NO}_{2}}{ }^{-}$ & ${\mathrm{N}-\mathrm{NO}_{3}}^{-}$ & $\mathrm{P}-\mathrm{PO}_{4}{ }^{3-}$ & Pe-Chl $a$ \\
\hline Diatoms & -0.051 & -0.200 & $-0.464^{a}$ & 0.127 & $0.317^{b}$ & $0.275^{b}$ & $0.437^{a}$ & $0.577^{\mathrm{a}}$ & $0.354^{a}$ \\
\hline Dinoflagellates & 0.072 & -0.023 & $-0.285^{b}$ & $0.410^{\mathrm{a}}$ & 0.221 & $0.265^{b}$ & 0.237 & 0.227 & 0.118 \\
\hline Euglenophytes & 0.111 & -0.013 & $-0.294^{b}$ & $0.444^{\mathrm{a}}$ & 0.197 & 0.197 & $\mathbf{0 . 2 7 3}^{\mathrm{b}}$ & 0.194 & 0.088 \\
\hline Cryptophytes & 0.123 & 0.006 & $-0.292^{b}$ & $0.446^{a}$ & 0.186 & 0.179 & $\mathbf{0 . 2 7 3}^{\mathrm{b}}$ & 0.189 & 0.101 \\
\hline Prasinophytes & -0.093 & -0.096 & $-0.249^{b}$ & 0.069 & 0.236 & 0.222 & 0.129 & $0.297^{b}$ & -0.081 \\
\hline Prymnesiophytes & 0.043 & 0.019 & -0.247 & $\mathrm{0.403}^{\mathrm{a}}$ & 0.173 & 0.152 & 0.197 & 0.166 & 0.025 \\
\hline Cyanobacteria & 0.117 & 0.050 & $-0.307^{b}$ & $0.470^{a}$ & 0.206 & 0.214 & $\mathbf{0 . 2 9 3}^{\mathrm{b}}$ & 0.201 & 0.218 \\
\hline
\end{tabular}

Bold numbers are those that show significant correlation: ${ }^{\mathrm{a}} \mathrm{p}<0.01,{ }^{\mathrm{b}} \mathrm{p}<0.05$

The appearance of phytoplankton blooms during the culture period, such as prasinophytes, cyanobacteria and cryptophytes blooms, can have detrimental effects on shrimp and water quality. All the phytoplankton blooms observed in this experiment, had a short duration and were produced in different tanks during the final phase of the culture period (days 31,38 and 45). In this period, $\mathrm{P}^{-\mathrm{PO}_{4}{ }^{3-} \text { y N-NO}}{ }^{-}$accumulated from shrimp excretions and from the nitrification of nitrogen compounds (TAN and $\mathrm{N}^{-\mathrm{NO}_{2}}{ }^{-}$). According to several authors,

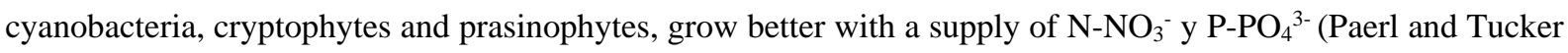
1995, Šupraha et al. 2014, and Reed et al. 2016). In this experiment, this is corroborated by the significant positive correlation between $\mathrm{N}^{-\mathrm{NO}_{3}}{ }^{-}$and both cryptophytes and cyanobacteria, and the positive correlation of P$\mathrm{PO}_{4}{ }^{3-}$ and prasinophytes (Table 3). Cyanobacteria blooms are common in shrimp farming, and are more common in low light conditions (Smith et al. 2008).

The following signature pigments were detected in periphyton samples (Table 4): peridinin, 19'butafucoxantyhin, fucoxanthin, 19'-hexafucoxantyhin neoxanthin, prasinoxanthin, violaxanthin, diadinoxanthin, alloxanthin, zeaxanthin and chlorophyll $b$. According to pigment analysis these eight periphyton groups were present: diatoms, dinoflagellates, chlorophytes, cryptophytes, euglenophytes, prasinophytes, prymnesiophytes and cyanobacteria. Like phytoplankton, a Kruskal-Wallis analysis was performed to detect statistically significant differences in groups abundance between tanks. In Table 5, we summarize periphyton statistics both for absolute composition (absolute contribution to chlorophyll $a, \mu \mathrm{g} / \mathrm{m}^{2}$ ) and relative composition (percentage of 
total chlorophyll $a, \%)$. In tables 4 and 5, statistically significant differences are assessed according to KruskalWallis results. There were no significant differences $(P>0.05)$ in signature pigments from periphyton and periphyton abundances between different densities of shrimp.

Table 4. Concentration of signature pigments and chlorophyll $a$ presents in the periphyton. The table show the percentile 10 (P 10), percentile 25 (P 25), percentile 75 (P 75), percentile 90 (P 90), maximum and average \pm standard deviation (SD) values.

\begin{tabular}{|c|c|c|c|c|c|c|}
\hline & \multicolumn{6}{|c|}{ Periphyton signature pigments concentration $(\mu \mathrm{g} / \mathrm{L})$} \\
\hline Signature pigments & P 10 & P 25 & P 75 & P 90 & Maximum & Average \pm SD \\
\hline Peridinin & 0.00 & 0.00 & 0.00 & 0.00 & 3.50 & $0.07 \pm 0.50$ \\
\hline 19'-butafucoxantyhin & 0.00 & 0.00 & 0.00 & 17.78 & 55.65 & $3.38 \pm 10.00$ \\
\hline Fucoxanthin & 11.84 & 23.27 & 174.14 & 309.71 & 1254.01 & $144.00 \pm 210.47$ \\
\hline 19'-hexafucoxantyhin & 0.00 & 0.00 & 0.00 & 0.00 & 76.28 & $1.89 \pm 11.08$ \\
\hline Neoxanthin & 0.00 & 0.00 & 0.00 & 0.00 & 36.97 & $1.93 \pm 7.42$ \\
\hline Prasinoxanthin & 0.00 & 0.00 & 10.97 & 43.27 & 201.79 & $13.21 \pm 33.25$ \\
\hline Violaxanthin & 0.00 & 0.00 & 4.49 & 12.16 & 34.07 & $3.47 \pm 6.40$ \\
\hline Diadinoxanthin & 0.00 & 0.00 & 6.84 & 15.67 & 66.75 & $6.88 \pm 13.22$ \\
\hline Alloxanthin & 0.00 & 0.00 & 0.00 & 0.00 & 1.17 & $0.02 \pm 0.17$ \\
\hline Zeaxanthin & 0.00 & 0.00 & 2.35 & 8.16 & 103.01 & $5.70 \pm 18.72$ \\
\hline Chlorophyll $b$ & 0.00 & 0.00 & 0.00 & 9.64 & 149.26 & $5.06 \pm 21.89$ \\
\hline Chlorophyll $a$ & 4.43 & 25.31 & 168.09 & 321.20 & 925.65 & $134.42 \pm 191.50$ \\
\hline
\end{tabular}

Data obtained from 54 periphyton samples $(n=54)$. 
Table 5. Periphyton statistics both for absolute and relative contribution to total chlorophyll $a$. The table show the percentile 10 (P 10 ), percentile 25 (P 25 ), percentile 75 (P 75), percentile 90 (P 90), maximum and average \pm standard deviation (SD) values.

\begin{tabular}{|c|c|c|c|c|c|c|c|c|c|c|c|c|}
\hline & \multicolumn{6}{|c|}{ Periphyton absolute contribution to chlorophyll $a\left(\mu \mathrm{g} / \mathrm{m}^{2}\right)$} & \multicolumn{6}{|c|}{ Periphyton relative contribution to chlorophyll $a(\%)$} \\
\hline Groups & P 10 & P 25 & $\mathbf{P} 75$ & P 90 & Maximum & Average \pm SD & P 10 & $\mathbf{P} 25$ & $\mathbf{P} 75$ & P 90 & Maximum & Average \pm SD \\
\hline Diatoms & 0.00 & 47.21 & 97.83 & 100.00 & 415.43 & $72.57 \pm 154.45$ & 0.00 & 4.65 & 106.37 & 192.29 & 100.00 & $67.92 \pm 36.33$ \\
\hline Dinoflagellates & 0.00 & 0.00 & 0.00 & 0.00 & 2.16 & $0.04 \pm 0.31$ & 0.00 & 0.00 & 0.00 & 0.00 & 10.81 & $0.20 \pm 1.56$ \\
\hline Euglenophytes & 0.00 & 0.00 & 0.00 & 46.97 & 60.58 & $3.07 \pm 10.82$ & 0.00 & 0.00 & 0.00 & 0.01 & 56.82 & $4.84 \pm 19.21$ \\
\hline Chlorophytes & 0.00 & 0.00 & 1.65 & 7.82 & 19.68 & $1.97 \pm 4,81$ & 0.00 & 0.00 & 0.88 & 10.15 & 44.94 & $2.70 \pm 7.85$ \\
\hline Cryptophytes & 0.00 & 0.00 & 0.00 & 0.00 & 3.07 & $0.07 \pm 0.45$ & 0.00 & 0.00 & 0.00 & 0.00 & 1.68 & $0.04 \pm 0.25$ \\
\hline Prasinophytes & 0.00 & 0.00 & 19.31 & 83.46 & 107.58 & $10.41 \pm 21.48$ & 0.00 & 0.00 & 14.39 & 40.66 & 100.00 & $15.84 \pm 30.81$ \\
\hline Prymnesiophytes & 0.00 & 0.00 & 0.00 & 0.30 & 213.62 & $5.23 \pm 30.96$ & 0.00 & 0.00 & 0.00 & 1.30 & 66.51 & $1.99 \pm 9.72$ \\
\hline Cyanobacteria & 0.00 & 0.00 & 2.26 & 29.74 & 108.29 & $7.71 \pm 23.77$ & 0.00 & 0.00 & 2.22 & 8.27 & 65.38 & $6.47 \pm 13.80$ \\
\hline
\end{tabular}

Data obtained from 54 periphyton samples $(\mathrm{n}=54)$. 
Chla concentration in periphyton had mean values of $101.07 \mu \mathrm{g} / \mathrm{m}^{2}$, but maximum values of $441.42 \mu \mathrm{g} / \mathrm{m}^{2}$ were detected in tank 1 on day 45. Mean Chla values are similar to those observed by Khatoon et al. (2007a) on the same type of surface (PVC) after 45 days of culture, although other authors observed superior values in this substrate (Thompson et al. 2002; Sruthisree et al. 2015). Shrimps graze on periphyton (Ballester et al. 2007), so the increase of available surfaces, through the placement of PVC sheets in the tank, may increase of periphyton biomass and improve shrimp productivity. But, the substrate is not the only variable that affects periphyton development, other environmental variables have an important influence (Khatoon et al. 2007a; Anand et al. 2013; Sruthisree et al. 2015).

Although periphyton was dominated by diatoms $(67.92 \%$ of $\mathrm{Chl} a)$ from the beginning of the culture, a higher percentage of other taxonomic groups was detected than in phytoplankton. The most abundant groups, apart from diatoms, were prasinophytes $(15.84 \%)$, cyanobacteria $(6.47 \%)$ and euglenophytes $(4.84 \%)$ as shown in table 5. The rest of groups had a mean contribution lower than $3 \%$ of Chla. Although most of the samples were dominated by diatoms, the punctual dominance of other periphyton groups was observed, such as euglenophytes on day $10(\operatorname{tank} 8)$, day $17(\operatorname{tank} 1)$ and day $45(\operatorname{tank} 8)$, prasinophytes on day $10(\operatorname{tanks} 1,6$ and 7), day 17 (tanks 2 and 6) and day 31 (tank 2), prymnesiophytes on day 38 (tank 4) and cyanobacteria on day 31 (tank 8). The incidence of these high percentages was limited since they were isolated cases, that happened on one tank only and disappeared in the next analysis, returning to show very low concentration such as those observed before the appearance of blooms.

Chla concentration evolution in periphyton samples by group is represented (Fig 2). In this experiment, the same as with phytoplankton, no Chla was detected before day 10 in periphyton samples. On day 10, periphyton absolute abundance was $97 \mu \mathrm{g} / \mathrm{m}^{2}$ of Chla, mainly due to diatoms and prasinophytes. These two groups abundance decreased on day 17, but later recovered. Since day 24 until the end of the experiment, a progressive increase in total Chla was observed, reaching a maximum of $129 \mu \mathrm{g} / \mathrm{m}^{2}$ on day 38 . This increase was mainly due to the growth of cyanobacteria and prymnesiophytes (14 and $9 \mu \mathrm{g} / \mathrm{m}^{2}$ of Chla respectively), while diatoms and prasinophytes maintained constant levels around 84 and $13 \mu \mathrm{g} / \mathrm{m}^{2}$ of Chla respectively. 


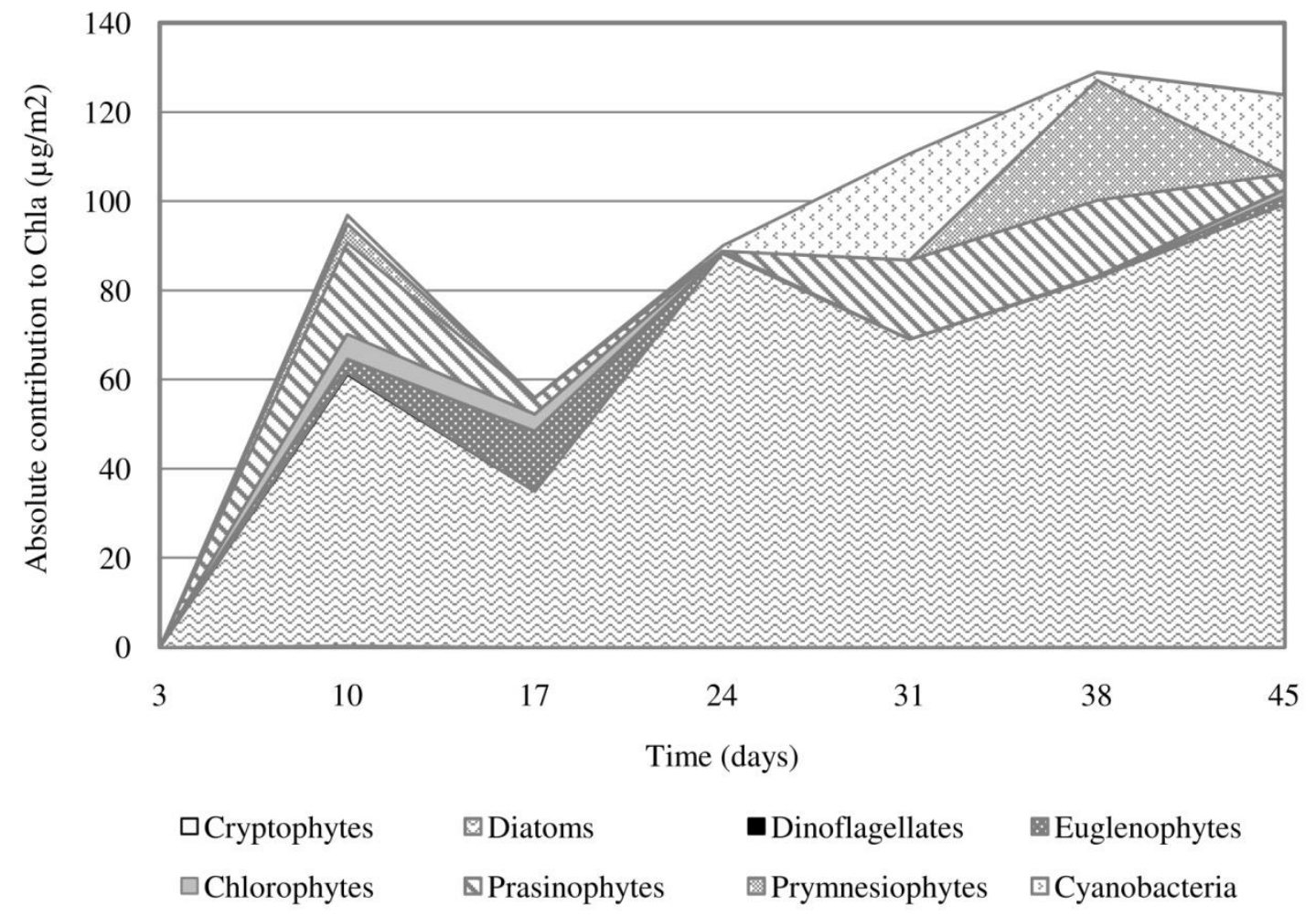

Fig. 2 Periphyton groups mean contribution to chlorophyll $a$ concentration $\left(\mu \mathrm{g} / \mathrm{m}^{2}\right)$ temporal evolution.

Table 6 shows rank correlation matrix (Spearman's) between environmental and biological variables with periphyton groups, less significant correlations were observed than with phytoplankton groups. The $\mathrm{pH}$ did not have significant correlation with any group. Salinity was positively correlated with two of the three major groups (diatoms and prasinophytes). Some authors have observed that high salinity favors the proliferation of periphyton on aquaculture tanks, fundamentally diatoms (Khandeparker et al. 2017). Dissolved oxygen was directly correlated with chlorophytes, which were more abundant at the beginning of the experiment, and inversely correlated with dinoflagellates, which were more abundant at the end when oxygen was lower. Temperature was in general positively correlated with some periphyton groups, this positive effect of high temperatures has also been observed by other authors (Phinney and McIntire 1965; Zhang et al. 2009). Nutrient significant correlation with periphyton groups was minor as compared with phytoplankton. Only TAN was

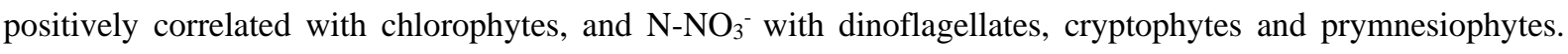
Chen (2001) also observed that chlorophytes easily assimilate TAN. The scarcely significant correlations suggest that environmental variables played a minor role in determining periphyton development. The major role must have been played by the different colonization capacity, typical of each microalgae group. The colonization 
process is highly dependent on phytoplankton composition (Khandeparker et al. 2017). Diatoms are one of the first colonizers because they generate a large amount of extracellular polymeric substance, which helps them to bind to the substrate (Hanlon et al. 2006, Choudhary et al. 2017). Also, diatoms with apical pads adhere easily to the substratum and usually form the first periphyton layer, that serves as anchorage to other groups such as stalk forming species (Ács et al. 2000). As shown in Table 6, there is a significant correlation between periphyton diatoms and phytoplankton biomass, which main contributor are diatoms. During the first phase of surface colonization, a smaller variety of groups is observed in periphyton. Over time the number of groups and their abundance increases (Ács et al. 2000; Jöbgen et al. 2004; Khatton et al. 2007a; Zhang et al. 2012). The main groups present in phytoplankton (diatoms, euglenophytes, prasinophytes, prymnesiophytes and cyanobacteria) have species that generate extracellular polymeric substance that can facilitate their adhesion to the periphyton (Claquin et al. 2008; Brake and Hasiotis 2012; Eldridge et al. 2012; Choudhary et al. 2017). The thick periphyton cover could be responsible of stabilizing the diatoms growth at the end of the study period.

Table 6. Rank correlation matrix (Spearman's) between environmental and biological variables (Salinity, T -

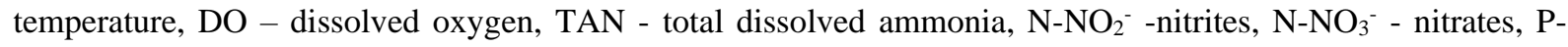
$\mathrm{PO}_{4}{ }^{3-}$ - phosphates, and $\mathrm{Ph}-\mathrm{Chl} a$ - total chlorophyll $a$ in the phytoplankton) and periphyton groups.

\begin{tabular}{|c|c|c|c|c|c|c|c|c|c|}
\hline & Salinity & $\mathrm{pH}$ & $\mathrm{DO}$ & $\mathrm{T}$ & $\mathrm{TAN}$ & $\mathrm{N}^{-\mathrm{NO}_{2}}{ }^{-}$ & $\mathrm{N}^{-\mathrm{NO}_{3}}{ }^{-}$ & $\mathrm{P}_{-\mathrm{PO}_{4}}{ }^{-}$ & $\mathrm{Ph}^{-C h l} a$ \\
\hline Diatoms & $\mathbf{0 . 2 6 4}^{\mathbf{b}}$ & 0.012 & -0.223 & 0.055 & 0.040 & -0.143 & 0.139 & 0.026 & $\mathbf{0 . 3 8 3}^{\mathbf{a}}$ \\
\hline Dinoflagellates & 0.062 & 0.102 & $\mathbf{- 0 . 2 5 8}^{\mathbf{b}}$ & $\mathbf{0 . 2 6 2}^{\mathbf{b}}$ & 0.141 & 0.018 & $\mathbf{0 . 2 8 1}^{\mathbf{b}}$ & 0.227 & 0.169 \\
\hline Euglenophytes & 0.080 & -0.078 & -0.002 & -0.103 & -0.100 & 0.038 & 0.054 & 0.083 & 0.113 \\
\hline Chlorophytes & $\mathbf{0 . 2 5 4}^{\mathbf{b}}$ & 0.200 & $\mathbf{0 . 2 7 3}$ & -0.122 & $\mathbf{0 . 4 0 5}^{\mathbf{b}}$ & -0.085 & -0.043 & -0.189 & 0.007 \\
\hline Cryptophytes & 0.043 & 0.070 & -0.198 & 0.217 & 0.175 & 0.065 & $\mathbf{0 . 2 8 1}^{\mathbf{b}}$ & 0.172 & 0.193 \\
\hline Prasinophytes & $\mathbf{0 . 2 6 5}^{\mathbf{b}}$ & 0.013 & 0.074 & -0.0114 & -0.143 & 0.053 & -0.019 & 0.032 & 0.117 \\
\hline Prymnesiophytes & $\mathbf{0 . 2 6 1}^{\mathbf{b}}$ & 0.003 & -0.220 & $\mathbf{0 . 2 5 3}^{\mathbf{b}}$ & 0.135 & 0.184 & $\mathbf{0 . 3 5 7}^{\mathbf{a}}$ & 0.221 & $\mathbf{0 . 2 9 5}^{\mathbf{b}}$ \\
\hline Cyanobacteria & -0.037 & -0.030 & -0.237 & $\mathbf{0 . 3 9 6}^{\mathbf{a}}$ & 0.170 & 0.093 & 0.158 & 0.011 & 0.212 \\
\hline
\end{tabular}

Bold numbers are those that show significant correlation: ${ }^{\mathrm{a}} \mathrm{p}<0.01,{ }^{\mathrm{b}} \mathrm{p}<0.05$. 
The dominance of diatoms and cyanobacteria to a lesser extent, on periphyton, coincides with observations by other authors (Thompson et al. 2002; Ballester et al. 2007; Khatoon et al. 2007a; Anand et al. 2013). The presence of euglenophytes, prasinophytes and prymnesiophytes in the periphyton has not been reported in most previous studies on aquaculture (Ballester et al. 2007; Kahoon et al. 2007a; Anand et al. 2013; BetancurGonzález et al. 2016). However, these studies analyzed periphyton composition by optic microscopy. In phytoplankton studies, carried out with optical microscopy, a large presence of these three groups is not reported either (Ballester et al. 2007; Kahoon et al. 2007a; Anand et al. 2013; Sruthisree et al. 2015; Betancur-González et al. 2016). On the other hand, the analysis of photosynthetic pigments by HPLC in aquaculture tanks has allowed to report the presence of these groups in phytoplankton (Jiang et al. 2016; Lemonnier et al. 2016; and Llario et al. 2018).

Due to the small size of these groups, optical microscopy often underestimates the abundance of these groups or even does not detect them. But even small concentrations of signature pigments are detected by HPLC, and this makes possible to quantify their abundance more accurately (Gocke et al. 2003; Devilla et al. 2005; Schlüter et al. 2006; Silva et al. 2008). The coexistence of diatoms, prasinophytes and prymnesiophytes in the periphyton increases its nutritional potential, since these groups are the most used as a source of food for shrimps (Benemann 1992; Jaime-Ceballos et al. 2006).

\section{Conclusion}

The use of HPLC coupled with CHEMTAX software is consolidated as an adequate tool for the determination of microalgae in aquaculture tanks. The analysis of signature pigments, has allowed to report the presence of previously undetected groups on periphyton, prasinophytes and prymnesiophytes, characterized by their high nutritional value. This is especially important in nurseries because shrimp grazing on periphyton can increase post-larvae survival, as periphyton is a supplementary feed source. In this experiment, diatoms dominated the phytoplankton due to its high yield in the use of all nutrients. However, the accumulation of nitrate and phosphate, could have caused the timely appearance of blooms of other phytoplankton groups. Diatoms also dominated periphyton. Nevertheless, nutrients had a minor effect on the development and composition of the periphyton, which was more affected by colonization processes. 


\section{ACKNOWLEDGEMENTS}

Financial support for this research was provided by Conselleria d'Educació, Investigació, Cultura i Esport of the Generalitat Valenciana, through the program VALi+D, file number ACIF/2014/244.

\section{CONFLICT OF INTEREST AND ETHICAL STATMENT}

The authors declare that they have no conflict of interest and all applicable institutional guidelines for the care and use of animals were followed by the authors.

\section{BIBLIOGRAPHY}

Ács É, Kiss KT, Szabó-Taylor K, Makk J (2000) Short-term colonization sequence of periphyton on glass slides in a large river (River Danube, near Budapest). Acta Bot Croat 100:135-156.

Alonso-Rodríguez R, Páez-Osuna F (2003) Nutrients. phytoplankton and harmful algal blooms in shrimp ponds: a review with special reference to the situation in the Gulf of California. Aquaculture 219(1-4):317-336. https://doi.org/10.1016/s0044-8486(02)00509-4

Anand PS, Kumar S, Panigrahi A, Ghoshal TK, Dayal JS, Biswas G, Sundaray JK, De D, Ananda Raja R, Deo AD, Pillai SM, Ravichandran P (2013) Effects of C:N ratio and substrate integration on periphyton biomass. microbial dynamics and growth of Penaeus monodon juveniles. Aquacult Int 21:511-524. https://doi.org/10.1007/s10499-012-9585-6 
Azim ME, Verdegem MC, Van Dam AA, Beveridge MC (2005) Periphyton: ecology, exploitation and management. Cambridge, USA.

Azim ME, Wahab MA, Van Dam AA, Beveridge MC, Verdegem MCJ (2001) The potential of periphyton-based culture of two Indian major carps, rohu Labeo rohita (Hamilton) and gonia Labeo gonius (Linnaeus). Aquac Res 32: 209-216. https://doi.org/10.1046/j.1365-2109.2001.00549.x

Ballester ELC, Wasielesky W, Cavalli RO, Abreu PC (2007) Nursery of the pink shrimp Farfantepenaeus paulensis in cages with artificial substrates: biofilm composition and shrimp performance. Aquaculture 269:355362. https://doi.org/10.1016/j.aquaculture.2007.04.003

Barbieri RC, Ostrensky A (2001) Camarões Marinhos: Reprodução. Maturação e Larvicultura. Voçosa, Brazil.

Baumgarten MGZ, Wallner-Kersanach M, Niencheski LFH (2010) Manual de análises em oceanografía química. Rio Grande, Brazil.

Benemann JR (1992) Microalgae aquaculture feeds. J Appl Phycol 4:233-245. https://doi.org/10.1007/bf02161209

Betancur-González EM, Ruales CAD, Gutiérrez LA (2016) Diversidad del perifiton presente en un sistema de producción de tilapia en biofloc. Revista Lasallista de Investigación 13:163-177. https://doi.org/10.22507/rli.v13n2a15

Blachier P (1998) Guide techniques du CREAA: l'élevage de la Crevette Imppériale. Le Château d'Oléron, France.

Brake SS, Hasiotis ST (2012) Potential metal attenuation by eukaryotic-dominated communities in acid mine drainage at the green valley coal mine site, Indiana. In: Comer J (ed.) Effects of abandoned mine land reclamation on ground and surface water quality in Indiana, 1st edn. Indiana geological survey special report 72 , Bloomington, Indiana, pp 285-300.

Brito LO, Santos IGS, Abreu JL, Araújo MT, Severi W, Gàlvez AO (2016) Effect of the addition of diatoms (Navicula spp.) and rotifers (Brachionus plicatilis) on water quality and growth of the Litopenaeus vannamei postlarvae reared in a biofloc system. Aquac Res 47:3990-3997. https://doi.org/10.1111/are.12849 
Burford M (1997) Phytoplankton dynamics in shrimp ponds. Aquac Res 28:351-360. https://doi.org/10.1111/j.1365-2109.1997.tb01052.x

Casé M, Leça EE, Leitão SN, Sant EE, Schwamborn R, de Moraes Junior AT (2008) Plankton community as an indicator of water quality in tropical shrimp culture ponds. Mar Pollut Bull 56:1343-1352. https://doi.org/10.1016/j.marpolbul.2008.02.008

Chen YC (2001) Immobilized microalga Scenedesmus quadricauda (Chlorophyta, Chlorococcales) for long-term storage and for application for water quality control in fish culture. Aquaculture 195:71-80. https://doi.org/10.1016/s0044-8486(00)00540-8

Choudhary P, Malik A, Pant KK (2017) Algal biofilm systems: an answer to algal biofuel dilemma. Algal Biofuels 77-96. https://doi.org/10.1007/978-3-319-51010-1_4

Claquin P, Probert I, Lefebvre S, Veron B (2008) Effects of temperature on photosynthetic parameters and TEP production in eight species of marine microalgae. Aquat Microb Ecol 51:1-11. https://doi.org/10.3354/ame01187

Coman GJ, Crocos PJ, Preston NP, Fielder D (2004) The effects of density on the growth and survival of different families of juvenile Penaeus japonicus (Bate). Aquaculture 229: 215-223. https://doi.org/10.1016/S0044-8486(03)00402-2

Crab R, Defoirdt T, Bossier P, Verstraete W (2012) Biofloc technology in aquaculture: beneficial effects and future challenges. Aquaculture 356:351-356. https://doi.org/10.1016/j.aquaculture.2012.04.046

Devilla RA, Brown MT, Donkin M, Readman JW (2005) The effects of a PSII inhibitor on phytoplankton community structure as assessed by HPLC pigment analyses, microscopy and flow cytometry. Aquat toxicol 71:25-38. https://doi.org/10.1016/j.aquatox.2004.10.002

Ebeling J, Timmons M, Bisogni J (2006) Engineering analysis of the stoichiometry of photoautotrophic, autotrophic, and heterotrophic removal of ammonia-nitrogen in aquaculture systems. Aquaculture 257:346-358. https://doi.org/10.1016/j.aquaculture.2006.03.019

Eldridge RJ, Hill DRA, Gladman BR (2012) A comparative study of the coagulation behaviour of marine microalgae. J Appl Phyco 24:1667-1679. https://doi.org/10.1007/s10811-012-9830-4 
Gaona CAP, Poersch LH, Krummenauer D, Foes GK, Wasielesky WJ (2011) The effect of solids removal on water quality, growth and survival of Litopenaeus vannamei in a biofloc technology culture system. International Journal of Recirculating Aquaculture 12. https://doi.org/10.21061/ijra.v12i1.1354

Gocke K, Meyerhöfer M, Mancera-Pineda JE, Vidal LA (2003) Phytoplankton composition in coastal lagoons of different trophic status in northern Colombia determined by microscope and HPLC-pigment analysis. Boletín de Investigaciones Marinas $\mathrm{y}$ Costeras-INVEMAR 32:263-278. https://doi.org/10.25268/bimc.invemar.2003.32.0.270

Grasshoff K (1976) Methods of Seawater Analysis. Weinheim, Germany: Wiley-VCH.

Guerrero-Galván SR, Páez-Osuna F, Ruiz-Fernández AC, Espinoza-Angulo R (1998) Seasonal variation in the water quality and chlorophyll $a$ of semi-intensive shrimp ponds in a subtropical environment. Hydrobiologia 391:33-45. https://doi.org/10.1023/A:100359062

Hagerthey SE, William-Louda J, Mongkronsri P (2006) Evaluation of pigment extraction methods and a recommended protocol for periphyton chlorophyll a determination and chemotaxonomic assessment. $\mathrm{J}$ Phycol 42:1125-1136. https://doi.org/10.1111/j.1529-8817.2006.00257.x

Hanlon ARM, Bellinger B, Haynes K, Xiao G, Hofmann, TA, Gretz MR, Ball AS, Osborn AM, Underwood GJC (2006) Dynamics of extracellular polymeric substance (EPS) production and loss in an estuarine, diatom-dominated, microalgal biofilm over a tidal emersio-immersion period. Limnol Oceanogr 51:79-93. https://doi.org/10.4319/lo.2006.51.1.0079

Harris GP (2012) Phytoplankton ecology: structure, function and fluctuation. Springer Science \& Business Media. https://doi.org/10.1007/978-94-009-4081-9

Hewitt DR, Duncan PF (2001) Effect of high water temperature on the survival. moulting and food consumption of Penaeus (Marsupenaeus) japonicus (Bate. 1888). Aquac Res 32:305-313. https://doi.org/10.1046/j.13652109.2001.00560.x

Hooker S, Firestone E, Claustre H, Ras J (2001) The first SeaWiFS HPLC analysis round-robin experiment (SeaHARRE-1). https://ntrs.nasa.gov/search.jsp?R=20010072242. Accessed 15 October 2017. 
Jaime-Ceballos B J, Hernández-Llamas A, Garcia-Galano T, Villarreal H (2006) Substitution of Chaetoceros muelleri by Spirulina platensis meal in diets for Litopenaeus schmitti larvae. Aquaculture 260:215-220. https://doi.org/10.1016/j.aquaculture.2006.06.002

Jiang T, Chen F, Yu Z, Lu L, Wang Z (2016) Size-dependent depletion and community disturbance of phytoplankton under intensive oyster mariculture based on HPLC pigment analysis in Daya Bay, South China Sea. Environ Pollut 219:804-814. https://doi.org/10.1016/j.envpol.2016.07.058

Jöbgen A, Palm A, Melkonian M (2004) Phosphorus removal from eutrophic lakes using periphyton on submerged artificial substrata. Hydrobiologia 528:123-142. https://doi.org/10.1007/s10750-004-2337-5

Kent M, Browdy CL, Leffler JW (2011) Consumption and digestion of suspended microbes by juvenile Pacific white $\quad$ shrimp Litopenaeus vannamei. Aquaculture 319:363-368. https://doi.org/10.1016/j.aquaculture.2011.06.048

Khandeparker L, Hede N, Eswaran R, Usgaonkar A, Anil AC (2017) Microbial dynamics in a tropical monsoon influenced estuary: Elucidation through field observations and microcosm experiments on biofilms. J Exp Mar Biol Ecol 497:86-98. https://doi.org/10.1016/j.jembe.2017.09.014

Khatoon H, Yusoff F, Banerjee S, Shariff M, Bujang JS (2007a) Formation of periphyton biofilm and subsequent biofouling on different substrates in nutrient enriched brackishwater shrimp ponds. Aquaculture 273:470-477. https://doi.org/10.1016/j.aquaculture.2007.10.040

Khatoon H, Yusoff F, Banerjee S, Shariff M, Mohamed S (2007b). Use of periphytic cyanobacterium and mixed diatoms coated substrate for improving water quality. survival and growth of Penaeus monodon Fabricius postlarvae. Aquaculture 271:196-205. https://doi.org/10.1016/j.aquaculture.2007.06.036

Krummenauer D, Poersch L, Romano LA, Lara GR, Encarnação P, Wasielesky W (2014) The effect of probiotics in a Litopenaeus vannamei biofloc ulture system infected with Vibrio parahaemolyticus. J Appl Aquac 26:370-379. https://doi.org/10.1080/10454438.2014.965575

Lemonnier H, Lantoine F, Courties C, Guillebault D, Nézan E, Chomérat N, Escoubeyrou K, Galinié C, Blockmans B, Laugier T (2016) Dynamics of phytoplankton communities in eutrophying tropical shrimp ponds affected by vibriosis. Mar Pollut Bull 110:449-459. https://doi.org/10.1016/j.marpolbul.2016.06.015

Lin YC, Chen JC (2001) Acute toxicity of ammonia on Litopenaeus vannamei (Boone) juveniles at different 
salinity levels. J Exp Mar Biol Ecol 259:109-119. https://doi.org/10.1016/s0022-0981(01)00227-1

Llario F, Rodilla M, Escrivá J, Falco S, Sebastiá-Frasquet MT (2018) Phytoplankton evolution during the creation of a biofloc system for shrimp culture. Int J Environl Sci Te 1-12. https://doi.org/10.1007/s13762-018$1655-5$

Macias-Sancho J, Poersch LH, Bauer W, Romano LA, Wasielesky W, Tesser MB (2014) Fishmeal substitution with Arthrospira (Spirulina platensis) in a practical diet for Litopenaeus vannamei: effects on growth and immunological parameters. Aquaculture 426:120-125. https://doi.org/10.1016/j.aquaculture.2014.01.028

Mackey MD, Mackey DJ, Higgins HW, Wright SW (1996) CHEMTAX, a program for estimating class abundances from chemical markers: application to HPLC measurements of phytoplankton. Mar Ecol Prog Ser 144:265-283. https://doi.org/10.3354/meps144265

Muller-Feuga A (2000) The role of microalgae in aquaculture: situation and trends. J Appl Phycol 12:527-534. https://doi.org/10.1023/A:100810

O'Kelly CJ, Sieracki ME, Thier EC, Hobson IC (2003) A transient bloom of Ostreococcus (chlorophyta, prasinophyceae) in west Neck Bay, Long Island, New York. J Phycol 39:850-854. https://doi.org/10.1046/j.1529-8817.2003.02201.x

Paerl HW, Tucker CS (1995) Ecology of blue-green algae in aquaculture ponds. J World Aquacult Soc 26:109131. https://doi.org/10.1111/j.1749-7345.1995.tb00235.x

Pandey PK, Bharti V, Kumar K (2014) Biofilm in aquaculture production. Afr J Microbiol Res 8:1434-1443. https://doi.org/10.5897/ajmr2013.6445

Phinney HK, McIntire CD (1965) Effect of temperature on metabolism of periphyton communities developed in laboratory streams. Limnol Oceanogr 10:341-345. https://doi.org/10.4319/lo.1965.10.3.0341

Preston NP, Burford MA, Jackson CJ, Crocos PJ (1995) Sustainable shrimp farming in Australia-prospects and constraints. Proceedings of PACON Sustainable Aquaculture 95:308-316.

Reed ML, Pinckney JL, Keppler CJ, Brock LM, Hogan SB, Greenfield DI (2016) The influence of nitrogen and phosphorus on phytoplankton growth and assemblage composition in four coastal, southeastern USA systems. Estuar Coast Shelf S 177:71-82. https://doi.org/10.1016/j.ecss.2016.05.002 
Renaud SM. Thinh LV. Lambrinidis G. Parry DL (2002) Effect of temperature on growth, chemical composition and fatty acid composition of tropical Australian microalgae grown in batch cultures. Aquaculture 211:195-214. https://doi.org/10.1016/s0044-8486(01)00875-4

Roy S, Llewellyn C, Egeland E, Johnsen G (2011) Phytoplankton pigments: characterization, chemotaxonomy and applications in oceanography. New York, USA.

Ryther JH, Officer CB (1981) Impact of nutrient enrichment on water uses. Estuaries and nutrients 247-261. https://doi.org/10.1007/978-1-4612-5826-1_11

Sanders JG, Cibik SJ, D'Elia CF, Boynton WR (1987) Nutrient enrichment studies in a coastal plain estuary: changes in phytoplankton species composition. Can J Fish Aquat Sci 44:83-90. https://doi.org/10.1139/f87-010

Schlüter L, Lauridsen TL, Krogh G, Jørgensen T (2006) Identification and quantification of phytoplankton groups in lakes using new pigment ratios, a comparison between pigment analysis by HPLC and microscopy. Freshwater Biol 51:1474-1485. https://doi.org/10.1111/j.1365-2427.2006.01582.x

Schveitzer R, Arantes R, Baloi MF, Costódio PFS, Arana LV, Seiffert WQ, Andreatta ER (2013) Use of artificial substrates in the culture of Litopenaeus vannamei (Biofloc System) at different stocking densities: Effects on microbial activity, water quality and production rates. Aquacult Eng 54:93-103. https://doi.org/10.1016/j.aquaeng.2012.12.003

Sebastiá MT, Rodilla M (2013) Nutrient and phytoplankton analysis of a Mediterranean Coastal area. Environ Manage 51:225-240. https://doi.org/10.1007/s00267-012-9986-3

Sebastiá MT, Rodilla M, Sanchis J, Altur V (2012) Influence of nutrient inputs from a wetland dominated by agriculture on the phytoplankton community in a shallow harbour at the Spanish Mediterranean coast. Agr Ecosyst Environ 152:10-20. https://doi.org/10.1016/j.agee.2012.02.006

Silva A, Mendes CR, Palma S, Brotas V (2008) Short-time scale variation of phytoplankton succession in Lisbon bay (Portugal) as revealed by microscopy cell counts and HPLC pigment analysis. Estuar Coast Shelf S 79:230-238. https://doi.org/10.1016/j.ecss.2008.04.004

Sinden A, Sinang SC (2016) Cyanobacteria in aquaculture systems: linking the occurrence, abundance and 
toxicity with rising temperatures. International Journal of Environmental Science and Technology, 13:28552862. https://doi.org/10.1007/s13762-016-1112-2

Smith JL, Boyer GL, Zimba PV (2008) A review of cyanobacterial odorous and bioactive metabolites: impacts and management alternatives in aquaculture. Aquaculture 280:5-20.

https://doi.org/10.1016/j.aquaculture.2008.05.007

Sruthisree C, Nayak H, Gowda G, Kumar B (2015) Evaluation of periphyton and biofilm growth on different substrates in shrimp culture pond. Journal of Experimental Zoology India 18:625-630.

Suda S, Watanabe MM, Otsuka S, Mahakahant A, Yongmanitchai W, Nopartnaraporn N, Yongding L, Day JG (2002) Taxonomic revision of water-bloom-forming species of oscillatorioid cyanobacteria. Int J Syst Evol Micr 52:1577-1595. https://doi.org/10.1099/ijs.0.01834-0

Šupraha L, Bosak S, Ljubešić Z, Mihanović H, Olujić G, Mikac I, Viličić D (2014) Cryptophyte bloom in a Mediterranean estuary: High abundance of Plagioselmis cf. prolonga in the Krka River estuary (eastern Adriatic Sea). Sci Mar 78:329-338. https://doi.org/10.3989/scimar.03998.28c

Thompson FL, Abreu PC, Wasielesky W (2002) Importance of biofilm for water quality and nourishment in intensive shrimp culture. Aquaculture 203:263-278. https://doi.org/10.1016/s0044-8486(01)00642-1

Utermohl M (1985) Zur Vervollkommnung der quantitative Phytoplankton-Methodik. Limnologie 9:1-38.

Viau VE, Souza DM, Rodríguez EM, Wasielesky W, Abreu PC, Ballester EL (2013) Biofilm feeding by postlarvae of the pink shrimp Farfantepenaeus brasiliensis (Decapoda, Penaidae). Aquacult Res 44:783-794. https://doi.org/10.1111/j.1365-2109.2011.03087.x

Wright S, Jeffrey S, Mantoura R, Llewellyn C, Bjornland T, Repeta D, Welschmeyer N (1991) Improved HPLC method for the analysis of chlorophylls and carotenoids from Mar Ecol Prog Ser 77:186-196. https://doi.org/10.3354/meps077183

Yusoff FM, Zubaidah MS, Matias HB, Kwan TS (2002) Phytoplankton succession in intensive marine shrimp culture ponds treated with a commercial bacterial product. Aquacult Res 33:269-278. https://doi.org/10.1046/j.1355-557x.2002.00671.x 
Zhang T, Li L, Song L, Chen W (2009) Effects of temperature and light on the growth and geosmin production of Lyngbya kuetzingii (Cyanophyta). J Appl Phyco 21:279-285. https://doi.org/10.1007/s10811-008-9363-z

Zhang W, Xu H, Jiang Y, Zhu M, Al-Rasheid KA (2012). Colonization dynamics in trophic-functional structure of periphytic protist communities in coastal waters. Mar Biol 159:735-748. https://doi.org/10.1007/s00227-0111850-0 